\title{
The Composition of Independent Board of Commissioner and Number of Board of Commissioner Meeting Towards Fraudulence of Financial Report (Empirical Study at Public Company Listed at Indonesia Stock Exchange in 2011-2017)
}

\author{
Sudarman $^{1}$, Aniqotunnafiah ${ }^{1} \&$ Masruri $^{2}$ \\ ${ }^{1}$ Institute of Economics AKA Semarang, Semarang, Indonesia \\ ${ }^{2}$ Muria Kudus University, Semarang, Indonesia \\ Correspondence: Sudarman, Institute of Economics AKA Semarang, Semarang, Indonesia.
}

Received: June 12, 2019

doi:10.5430/ijfr.v10n4p96
Accepted: July 16, 2019

Online Published: July 18, 2019

URL: https://doi.org/10.5430/ijfr.v10n4p96

\begin{abstract}
This study aims to obtain empirical evidence about the effect of corporate governance mechanisms on fraudulent financial reporting. The variables of corporate governance used are independent board composition, frequency of board commissioner meetings, and external auditor quality as moderating variables between the influences of independent board composition, number of board of commissioners meetings against fraudulent financial reporting. The population of this study was public companies listed on the Indonesia Stock Exchange in 2011 - 2017. The total samples of this study were 76 companies, consist of 38 companies reported committing fraudulently financial statements and 38 companies that did not cheat financial statements. Data analysis was carried out by descriptive analysis, crosstab and hypothesis testing using the logistic regression method. The results of this study indicate the composition of the independent board of commissioners and the frequency of board of commissioners meetings has a significant and negative effect on the fraudulent financial report. Also, the quality of external auditors can strengthen the influence of the composition of the independent board of commissioners and the number of board of commissioners meetings on the fraudulent financial reporting.
\end{abstract}

Keywords: fraudulent financial report, independent commissioners, number of board of commissioners meetings, and the quality of external auditors

\section{Introduction}

The desire to always be seen well by various parties often forces companies to manipulate certain parts of their reporting, so that in the end it happens to present false information. Frauds by companies to manipulate financial statements are better known as fraudulent financial reporting (Priantara, 2013).

The many cases that afflict several public companies make the stakeholders lose money, so companies need to make corporate governance better (Ismiyanti \& Prastichia, 2015; Rahmadhalina \& Chariri, 2016; Razali \& Arshad, 2014; Wicaksono \& Chariri, 2015). Komeite Nasional Kebijakan Governance or The National Governance Policy Committee (KNKG) (2008) establishes the principles that are expected to be implemented by the company in every aspect of the company's business, namely transparency, accountability, responsiveness, independence and fairness (Soni Warsono, 2009). By adhering to ethical principles, various company activities can synergize to achieve the goals of corporate governance, namely to provide added value to the company.

Corporate governance is believed to be able to prevent several factors that trigger fraud. The Forum for Corporate Governance in Indonesia (FCGI) defines corporate governance as a set of rules that regulate the relationship between shareholders, company managers, creditors, governments, employees and other internal and external stakeholders related to their rights and obligations. In other words, it is a system that regulates and controls the company. The issue of corporate governance in Indonesia was first started in 1998 when a global monetary crisis occurred, which caused Indonesia to experience a prolonged economic crisis.

Research conducted by the Asian Development Bank (ADB) in 1999 concluded that several factors were causing the financial crisis that occurred in Asia, including Indonesia. The critical factors were: (1) ineffective board of 
commissioners and board of directors; (2) lacking the company's internal control; (3) the absence of adequate disclosures in the company's financial statements; (4) the company's financial statements are presented improperly and are less compliant with organizational policies. The weak system of corporate governance in Indonesia at that time caused several companies to present manipulated financial reporting. Therefore the effectiveness of corporate governance needs to be improved so that management does not deviate from stakeholders (Priantara, 2013).

According to Razali and Arshad (2014), there are several indicators in measuring the quality of corporate governance, including: (1) the size of the board of commissioners, (2) the composition of independent commissioners, (3) audit committees, and (4) the effectiveness of internal audits. The board of commissioners has a vital role in the implementation of good corporate governance. The board of independent commissioners is part of the board of commissioners, consist of individuals outside the organization. The board of independent commissioners generally has better supervision of management, thus influencing the possibility of fraud in presenting financial statements carried out by managers (Razali \& Arshad, 2014). That is, the more independent the board of commissioners will further reduce the possibility of fraud in financial reporting. Contrary to the findings of Razali and Arshad (2014), Ismiyanti and Prastichia (2015) found that the existence of independent commissioners did not significantly reduce the possibility of fraudulent financial statements.

The research conducted by Ismiyanti and Prastichia (2015) aimed to examine the effect of corporate governance mechanisms consisting of a board of commissioners size, the board of commissioner composition, frequency of board of commissioner meetings, the largest shareholder, managerial ownership, length of the board of directors' tenure and auditor type. The finding shows the evidence that there is a significant positive relationship between the board of commissioner's size and the possibility of fraudulent financial statements, while the managerial ownership has a significant negative effect on the possibility of fraudulent financial statements. However, the composition of the board of independent commissioners, the number of board of commissioners meetings, the length of the board of directors' tenure, the biggest shareholder, and the type of auditor did not influence the possibility of fraudulent financial statements.

Salleh and Othman (2016) conducted a study on companies in Malaysia found that the frequency of board meetings can be used as a method to prevent accounting fraud from occurring. The frequency of the board of commissioners in conducting meetings allows the company to communicate often everything that happens in the company. So that when there are obstacles in the company, it can be overcome quickly, including control of financial statements so that fraud does not occur.

Apriliana and Agustina (2017) also found that the quality of external auditors had a positive effect in predicting the possibility of fraudulent financial reporting. The study indicates that qualified auditors as well as auditors affiliated with Big four reduce the company's possibility to present fraud financial statements. Herawaty (2009), Mutmainnah and Wardhani (2013), Khlif and Samaha (2016), Rahmadani and Haryanto (2017) and Buchanan (2018) revealed that the existence of Big 4 auditors able to increase the role of commissioners, independent commissioners, number of board meetings and audit committees in reducing or preventing fraudulent financial reporting.

Based on the results of previous studies, this study aims to strengthen previous research on the effect of the composition of independent commissioners and board of commissioners' meetings on the possibility of fraud in financial reporting at public companies listed on the Indonesia Stock Exchange (IDX) and the quality of external auditors as moderating variables.

\section{Theoretical Thinking Framework and Hypothesis Formulation}

\subsection{Agency Theory}

Jensen and Meckling (1976) stated that agency relationships arise because of a contract between the principal and the agent by delegating some decision-making authority to the agent. By the agreement, principals give authority to the agent to make decisions. In practice, the company managers who act as agents with responsibility increase the profits of the owners (principals), but managers also have an interest in maximizing their welfare (Ujiyantho \& Pramuka, 2007). When managers have an interest in maximizing their welfare, it can allow the agent not to act in the interests of the principal.

\subsection{Fraudulent Financial Reporting}

Fraudulent Financial Reporting is intentional or negligent in reporting financial statements where the financial statements presented are not by generally accepted accounting principles. This negligence or intentional nature is material so that it can influence the decisions that will be taken by interested parties. 




Figure 1. Fraudulent financial reporting

\subsection{Effect of the Board of Independent Commissioners' Composition on the Fraudulent Financial Reporting}

The Board of Independent Commissioners is an important aspect of corporate governance and has an impact on the effectiveness of the board of commissioners' performance (Rezaee, 2007). The board of independent commissioners helps to balance the functions of supervision and consideration in making the necessary decisions. The existence of the board of independent commissioners must encourage the creation of Good Corporate Governance by creating an objective atmosphere and equality among various interests including the interests of the company and the interests of stakeholders. The composition of the board of independent commissioners is at least $30 \%$ (thirty percent) of the total board members. The optimal board of independent commissioners structure allows the company to have effective governance in supporting the company's performance and minimize the occurrence of fraud in the company.

Ismiyanti and Prastichia (2015) opined that the percentage of the board of independent commissioners does not affect fraudulent financial reporting. However, Chen, Firth, Gao, and Rui (2006), Razali and Arshad (2014) argue that the composition of independent commissioners has a negative effect on the possibility of fraud in financial reporting. It means that the increase of composition of the board of independent commissioners in the company, the possibility of fraudulent financial statements will be smaller. With the existence of the board of independent commissioners, it can guarantee the transparency of financial statements so that shareholders will get quality information. Based on these statements, the hypothesis formulation is:

H1: The composition of the board of independent commissioners has a negative effect on fraudulent financial reporting.

\subsection{Effect of Number of Board of Commissioners Meetings on Fraudulent Financial Reporting}

Board of Commissioners meetings facilitated as a media for communicating between members of the board of commissioners in carrying out their duties as the company's management supervisory board. Financial Services Authority Regulation Number 33/pojk04/2014 concerning directors and commissioners of issuers or public companies article 31 states that the board of commissioners must hold a meeting at least once every two months. Such meetings can be held only if a majority of all members of the board of commissioners are present and the presence of the board of commissioners in the meeting must be disclosed in the company's annual report. It is expected that the frequency of increasingly frequent board meetings, can dispel management of fraud because the supervision carried out by the board of commissioners is getting better. Not only that, with the regular board of commissioners meetings, it is also expected to minimize agency costs for monitoring agent behaviour (Jensen \& Meckling, 1976).

Salleh and Othman (2016) found that there was a significant effect between the frequency of board meetings and corporate fraud. Mahesarani and Chariri (2015) also found that the number of board of commissioner meetings affected fraudulent financial reporting. These findings indicate that board meetings can be used to monitor companies in preventing fraud. A higher frequency of board meetings shows that the boards are aware of the condition of the company and can closely monitor the company's operational activities. However, research conducted by Ismiyanti and Prastichia (2015) states that the number of board of commissioner meetings does not affect the possibility of fraudulent financial reporting.

Based on the statement, it can be formulated the hypotheses as follow:

$\mathrm{H} 2$ : The number of board commissioner meetings negatively affects the fraudulent financial reporting. 


\subsection{Effect of the External Auditor Quality and the Composition of the Board of Independent Commissioners on the Fraudulent Financial Reporting}

The auditor is an important part of the corporate monitoring system, especially in assisting the board of commissioners. The concept of Corporate Governance requires financial reports that are of high quality and meet transparency standards so that the financial condition of a corporation can be adequately illustrated (Lukviarman, 2016). To convince other owners and stakeholders that the information they receive is unbiased information, the Board of independent Commissioners asks independent auditors to conduct an audit of information provided by management as their accountability report to the company's stakeholders. Independent commissioners may not rashly give their consent to the issuer's transactions or activities, which materially contain incorrect or misleading information. Therefore the role of external auditors greatly assists the task of independent commissioners in the company's supervision process (Nazarudin, Suliyanto, \& Pinasti, 2014).

Research conducted by Herawaty (2009) found that earnings management can be minimized by a monitoring mechanism by independent commissioners and external auditors. Buchanan (2018) also state that the increase in supervision by auditors and commissioners will reduce management's opportunistic behaviour so that fraud within the company will be minimized. Unlike Haerawaty and Buchanan, (Nazarudin et al., 2014) stated that auditor quality could not moderate the influence of the role of the board of commissioners and directors on earnings management.

Based on the statements above, the hypothesis that can be formulated is:

H3a: External Auditor Quality strengthens the relationship between the composition of the Board of independent Commissioners and the Fraudulent Financial Reporting

2.6 Effect of External Auditor Quality and Number of Board of Commissioners Meetings on Fraudulent Financial Reporting

The performance of public accountants will be reported by the board of the audit committee to the board of commissioners and will be discussed through the board of commissioners meeting. Frequently, the board of commissioners conducts meetings, it is possible to increase awareness and reduce or prevent fraud in the company. In addition, for there is good communication between the board of commissioners and the audit committee where external auditors are under supervision, it can reduce the possibility of management opportunities to get closer to external auditors who have the potential to influence audit results before being submitted to the board of commissioners (Lukviarman, 2016). Therefore in maintaining its reputation, a good result of the assessment conducted by the board of commissioners, that the performance of the company's external auditor is good, the external auditor will maximize its performance by the professional code of ethics.

Chen et al. (2006) revealed that the quality of external auditors could be measured through the size of the Public Accounting Firm that examined the company. Khlif and Samaha (2016) stated that the quality of internal controls and activities of audit committees increased when the company was audited by Big auditors 4. Similarly, Apriliana and Agustina (2017) found that the quality of external auditors was influential in predicting fraud in financial reporting. Buchanan (2018) revealed that if there is an increase in communication between auditors and the board, it will prevent management from acting opportunistically in conducting management earnings. The opposite is Buchanan (2018) also found evidence that auditor oversight without communication with the board triggered management earnings by management who had opportunistic behavior. Likewise, Mahesarani and Chariri (2015) found that the interaction of the quality of external auditors and board meetings did not affect fraudulent financial reporting. Based on these statements, the hypotheses are:

H3b: External Auditor Quality strengthens the relationship between the Number of Board of Commissioners Meetings to Fraudulent Financial Reporting

\section{Research Methods}

\subsection{Research Variable}

This study aims to analyze the corelation between the composition of independent commissioners and board of commissioners meetings with fraudulent financial reporting. In this study, numbers were used as indicators of research to answer research problems or know as quantitative methods. 
Table 1. Research variable

\begin{tabular}{|c|c|c|}
\hline Variable & Definition & Measurement \\
\hline $\begin{array}{l}\text { Dependent } \\
\text { Variable: } \\
\text { Fraudulent } \\
\text { Financial } \\
\text { Reporting }\end{array}$ & $\begin{array}{l}\text { Public companies that have been } \\
\text { proven to be fraudulent due to } \\
\text { violations of the Financial } \\
\text { Services Authority or Otoritas } \\
\text { Jasa Keuangan } \quad \text { OJK) } \\
\text { regulations namely VIII.G.7 } \\
\text { concerning the presentation and } \\
\text { disclosure of financial statements }\end{array}$ & $\begin{array}{l}\text { Dummy Variable: } \\
\text { Code } 1 \text { (one) for companies that have been proven } \\
\text { to have committed fraud because they violated } \\
\text { OJK (financial services authority) regulations that } \\
\text { contained fraud and sanctions. } \\
\text { Code } 0 \text { (zero) for companies that do not commit } \\
\text { financial reporting fraud }\end{array}$ \\
\hline $\begin{array}{l}\text { Independent } \\
\text { Variable: } \\
\text { Composition of the } \\
\text { Board of } \\
\text { Independent } \\
\text { Commissioners }\end{array}$ & $\begin{array}{l}\text { The number of board members } \\
\text { coming from outside the } \\
\text { company to the entire board } \\
\text { members }\end{array}$ & $\begin{array}{l}\text { The ratio used to measure this variable: } \\
\text { Independent Commissioner }= \\
\frac{\Sigma \text { Independent Commissioner }}{\Sigma \text { Commissioner Board }} \times 100\end{array}$ \\
\hline $\begin{array}{l}\text { Number of Board } \\
\text { of Commissioners } \\
\text { Meetings }\end{array}$ & $\begin{array}{l}\text { A number of the board of } \\
\text { commissioners meetings in a } \\
\text { year. } \\
\text { OJK Regulation No. } 32 \text { of } 2014 \\
\text { namely board of commissioners } \\
\text { meetings at least four times a } \\
\text { year. }\end{array}$ & $\begin{array}{l}\text { Measurement of this variable is by the nominal } \\
\text { scale by calculating: } \\
\text { Number of Board of Commissioners Meetings in } \\
\text { a year (Ismiyanti and Prastichia 2015, Shalleh et } \\
\text { al. (2016) }\end{array}$ \\
\hline $\begin{array}{l}\text { Moderating } \\
\text { variable: External } \\
\text { Auditor Quality }\end{array}$ & $\begin{array}{l}\text { The auditors who audit the } \\
\text { company are auditors from the } \\
\text { Public Accounting Firm } \\
\text { affiliated with Big4 (Deloitte } \\
\text { Tunche Tomatsu, } \\
\text { Pricewaterhouse Cooper, Ernst \& } \\
\text { Young, and KPMG) }\end{array}$ & $\begin{array}{l}\text { Measurement of this variable uses a dummy } \\
\text { variable with a nominal scale: } \\
\text { Code } 1 \text { if the company uses an auditor from KAP } \\
\text { affiliated with Big } 4 \\
\text { Code } 0 \text { If the company does not use an auditor } \\
\text { from KAP affiliated with Big4 }\end{array}$ \\
\hline
\end{tabular}

\subsection{Population and Sample}

The population in this research is all public companies registered on the Indonesia Stock Exchange from 2011 to 2017. The consideration is that public companies have many shareholders that have a more accountable financial report. The sample used in this research is companies that commit fraudulent financial reporting and companies that do not commit fraudulent financial reporting. Data of companies that committed fraudulent financial reporting was obtained from the press release of the Financial Services Authority (OJK) report in 2011-2017 which contained a list of companies that got sanctions by the OJK for many types of violations. The sample data of companies that do not submit financial reporting were taken by purposive sampling and are companies that are in the same type of industry and have a range of assets that are by companies that commit fraud. Based on these criteria, the companies become samples with six years of observation (2011-2017) are as follows:

Table 2. Research sample

DESCRIPTION TOTAL

\begin{tabular}{ll}
\hline The companies which conducted fraudulent financial report & 38 \\
\hline In 2011 & 6 \\
\hline In 2012 & 12 \\
\hline In 2013 & 8 \\
\hline
\end{tabular}




\begin{tabular}{ll}
\hline In 2014 & 5 \\
\hline In 2015 & 4 \\
\hline In 2016 & 3 \\
\hline In 2017 & None \\
\hline The company which did not conduct fraudulent financial report & 38 \\
\hline Total & 76 \\
\hline
\end{tabular}

Source: Secondary Data processed based data from OJK 2018

\subsection{Analysis Method}

The method used in this research is the logistic regression test. Regression model to test the hypotheses formulated in this research is:

$$
\text { Ln } \frac{(\text { Fraud })}{(1-\text { Fraud })}=\beta 0+\beta 1 X 1+\beta 2 X 2+\beta 5 X 1 X 3+\beta 6 X 2 X 3+€
$$

Description:

Fraud: Variable dummy, code 1 (one) for companies that commit fraud, financial report, code 0 (zero) for companies non-fraud

$\beta 0$ : Constant

$\beta$ : Variable coefficient

$\mathrm{X} 1$ : The composition of the independent board of commissioners

$\mathrm{X} 2$ : The number of Board Meetings

X1X3: Composition interaction of independent commissioners and the quality of external auditors

X2X3: Number interaction of Board of Commissioners Meetings and the quality of external auditors

$€$ : Coefficient error

\section{Research Result and Discussion}

\subsection{Description of Research Object}

This research was conducted on public companies registered in the Indonesia Stock Exchange (BEI) which were given sanctions and cases by the "Otoritas Jasa Keuangan, or OJK" (Indonesia Financial Services Authority). Those public companies are companies registered in all industrial sectors on the IDX in 2011-2017. Table 3, the following are data obtained by researchers in the data collection.

Table 3. List of industries subjected sanctions and cases by OJK 2011-2017 and listed on the IDX for the period 2011-2017

\begin{tabular}{llll}
\hline No & Type of Industry & Total & Percentage \\
\hline $\mathbf{1}$ & Pharmaceuticals & 1 & $2,38 \%$ \\
\hline $\mathbf{2}$ & Metal \& Allied Product & 1 & $2,38 \%$ \\
\hline $\mathbf{3}$ & Textil & 1 & $2,38 \%$ \\
\hline $\mathbf{4}$ & Plastics \& Glass product & 1 & $2,38 \%$ \\
\hline $\mathbf{5}$ & Transportations services & 1 & $2,38 \%$ \\
\hline $\mathbf{6}$ & Advertising \& Media & 1 & $2,38 \%$ \\
\hline $\mathbf{7}$ & Food \& Beverage & 2 & $4,77 \%$ \\
\hline $\mathbf{8}$ & Tellecommunication & 2 & $4,77 \%$ \\
\hline
\end{tabular}




\begin{tabular}{llll}
\hline $\mathbf{9}$ & Agriculture, Foresty, Fishing & 3 & $7,14 \%$ \\
\hline $\mathbf{1 0}$ & Paper \& Allied Products & 3 & $7,14 \%$ \\
\hline $\mathbf{1 1}$ & Whole Sale \& Retail Trade & 3 & $7,14 \%$ \\
\hline $\mathbf{1 2}$ & Holding \& Other Investment Companies & 4 & $9,52 \%$ \\
\hline $\mathbf{1 3}$ & Mining, Quarrying, oil, gas extraction & 8 & $19,04 \%$ \\
\hline $\mathbf{1 4}$ & Real Estate \& Property & 11 & $26,19 \%$ \\
\hline Total companies sanctioned and disobey OJK rules listed in BEI in & 42 & $100 \%$ \\
$2011-2017$ & & &
\end{tabular}

The companies which did not present complete data related to research (4) variables in the financial report (period 2011 until 2017)

Total samples of fraud companies 38

Source: Data processed in 2018

This research requires an equal number of non-fraud companies, 38 companies as a comparison, as shown in Skousen, Smith, and Wright (2009). In choosing the non-fraud companies, this research conducted a comparison between fraud and non-fraud companies with the following criteria:

1. Year. This research identified non-fraud companies in the same period as a fraud in this research that is 2011-2017.

2. Industry. Fraud and non-fraud companies must be in the same industry.

3. Company size. This research uses the net sales size and total assets as company size.

The following is data for comparison on fraud and non-fraud companies presented in Table 4.

Table 4. Comparison of assets and sales of fraud \& non-fraud companies

\begin{tabular}{lllll}
\hline Industry & Fraud & & Non-fraud \\
\cline { 2 - 5 } & Asset & Sales & Asset & Sales \\
\hline Pharmaceuticals & 642.910 & 521.610 & 650.240 & 425.750 \\
\hline Metal \& Allied Product & 1.335 .800 & 354.677 & 1.467 .995 & 621.225 \\
\hline Textil & 1.820 .993 & 1.136 .424 & 1.289 .773 & 943.498 \\
\hline Plastics \& Glass product & 204.890 & 220.551 & 343.511 & 397.003 \\
\hline Transportations services & 840.645 & 734.908 & 1.924 .717 & 792.776 \\
\hline Advertising \& Media & 13.560 .332 & 5.606 .221 & 12.035 .683 & 5.122 .800 \\
\hline Food \& Beverage & 2.574 .557 & 832.445 & 2.943 .225 & 921.266 \\
\hline Tellecommunication & 5.680 .732 & 1.265 .883 & 4.228 .198 & 963.772 \\
\hline Agriculture, Foresty, Fishing & 1.332 .674 & 521.903 & 923.541 & 938.561 \\
\hline Paper \& Allied Products & 3.562 .837 & 1.276 .020 & 5.647 .004 & 1.498 .076 \\
\hline Whole Sale \& Retail Trade & 2.561 .553 & 921.667 & 1.820 .663 & 959.882 \\
\hline Holding \& Other Investment Companies & 3.470 .076 & 911.523 & 2.767 .992 & 1.017 .552 \\
\hline Mining, Quarrying, oil, gas extraction & 11.868 .224 & 6.305 .694 & 13.989 .221 & 5.420 .919 \\
\hline Real Estate \& Property & 9.356 .225 & 3.520 .889 & 7.676 .112 & 1.14 .236
\end{tabular}

Source: Secondary data which were processed in 2018 (in a million rupiahs) 


\subsection{Descriptive Statistics and Crosstabulation}

Descriptive statistics are related to the collection and presentation of data, which describes the independent variables used in this research. This analysis is to describe the mean, standard deviation, extreme values, that are the minimum and maximum values, and the standard deviation. For dummy variables is Fraud (If Fraud code 1 and if not Fraud code 0) and External Auditor (If using Big4 KAP code one if not given Code 0) Crosstab analysis is used because data is in nominal scale.

Table 5. Crosstab analysis

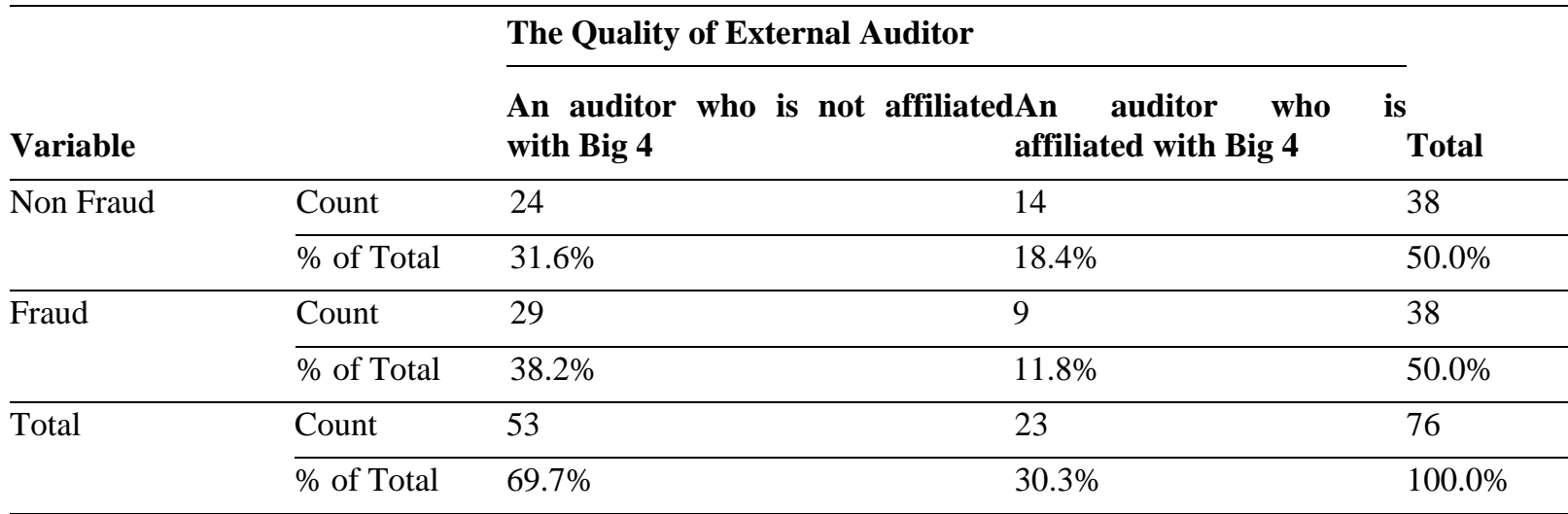

Source: Data processed in 2018

Table 6. Descriptive analysis

\begin{tabular}{llllllll}
\hline Variables & $\mathbf{N}$ & Mean & Median & Modus & Minimum & Maximum & Std.Deviation \\
\hline Fraud Non-Fraud & 76 & .50 & .50 & $0^{\mathrm{a}}$ & 0 & 1 & .503 \\
\hline $\begin{array}{l}\text { Independent Commissioner } \\
\text { (X1) }\end{array}$ & 76 & 44.36 & 53 & 50 & 17 & 67 & 10.681 \\
\hline Commissioner Meeting (X2) & 76 & 5.86 & 4.50 & 6 & 1 & 26 & 4.701 \\
\hline External Auditor (X3) & 76 & .50 & .00 & 0 & 0 & 1 & .462 \\
\hline
\end{tabular}

Source: Data processed in 2018

Table 5 above shows that companies that commit fraud amounted 38 (50\%) and companies that do not commit fraud amounted 38 (50\%). Companies that commit fraud consist of companies that use external auditors affiliated with Big 4 counted nine companies (11.8\%), and those that use external auditors but not affiliated with Big 4 amounted 29 companies (38.2\%). For companies that do not commit fraud, 14 companies use external auditors affiliated with Big4 (18.4\%) and 24 companies (31.6\%) use external auditors but are not affiliated with Big 4. Based on the data above, it can be concluded that fraud occurs more if the company uses an external auditor that is not affiliated with Big 4 and fraud will be prevented if the company uses an external auditor affiliated with Big 4.

Based on Table 6 above, it can be known that the composition variables of the independent board of commissioner show a minimum value of $17 \%$. The maximum value is $67 \%$, which means that most of the board of commissioners are independent commissioners. The average of these variables is $44.36 \%$, which shows that the average company observed has followed the rules of OJK Number 33 of 2014 that requires independent commissioners of each company to be at least $30 \%$ of all board of commissioners. The mode of this variable is 50 , which means that from the observation company there are independent commissioners. The median of these variables is 53 , and the standard deviation of this variable is 10,681 .

The variable number of board of commissioner meetings has a minimum value of 1 , which means that the number of board of commissioner meetings in a year is at least one time. The maximum value is 26 , which indicates that the biggest number of board of commissioner meetings is 26 times a year. The average of this variable is $5.86 \%$, or it can be concluded that the average board of commissioners meeting in a year in the observation sample is from 5 to 6 
meetings. This is reinforced by the Mode value of 6 , meaning that the sample companies often conduct meetings six times a year. The median is 4 , and the standard deviation of this variable is $4.70 \%$.

\subsection{Discussion of Research Results}

Hosmer and Lemeshow testing with a significance level (5\%) show that the amount of the statistical test Hosmer and Lemeshow's test goodness of fit test is 6.321 with a significant probability of 0.611 , the value that is far above 0.05 . Thus it can be concluded that the regression model can be said to be fit or suitable.

Test of the omnibus test (overall test) shows if the chi-square value obtained is 10.659 with a significance value of 0.038 lower than 0.05 , it can be concluded that the use of independent variables in the research model can simultaneously predict the dependent variable or can be said if the model is fit with data.

The testing to the determination coefficient of Nagelkerke's $R$ Square is 0.174 . It means that all the independent variables influence the dependent variable for $17.4 \%$, other variables influence the rest. Overall classification accuracy is $63.2 \%$ produced from $(24+24) / 76=0,63157 \times 100 \%=63,2 \%$.

\subsection{Hypothesis Testing}

Hypothesis testing is done by logistic regression analysis to determine the influence of each independent variable towards the dependent variable. If the significance level is $<0.05$, then $\mathrm{H} 1$ cannot be rejected or accepted. If the significance level $>0.05$, then $\mathrm{H} 1$ is rejected.

Table 7. Logistic regression analysis

\begin{tabular}{lllllll}
\hline Variables & B & S.E. & Wald & Df & Sig. & Exp(B) \\
\hline Independent Commissioner (X1) & -.020 & .028 & .521 & 1 & .042 & 1.020 \\
\hline Commissioner Meeting (X2) & -.137 & .121 & 1.295 & 1 & .025 & .872 \\
\hline External Audit (X3) & 3.164 & 4.725 & .448 & 1 & .503 & 23.666 \\
\hline $\mathrm{X} 3 \mathrm{X} 1$ & -.157 & .124 & 1.609 & 1 & .020 & .854 \\
\hline $\mathrm{X} 3 \mathrm{X} 2$ & -.291 & .207 & 1.983 & 1 & .016 & 1.338 \\
\hline Constant & -.268 & 1.556 & .030 & 1 & .050 & .765 \\
\hline Source: Data processed in 2018 & & & & & & \\
\hline
\end{tabular}

From the results of the logistic regression test above, the following results are obtained:

Table 8. Result of hypothesis

\begin{tabular}{lll}
\hline Hypothesis & Significance & Description \\
\hline H1: The influence of the composition of the independent board of & 0,042 & H1 accepted \\
commissioners towards fraudulent financial reporting & \\
\hline H2: The influence of the number of board of commissioners meetings & 0,025 & H2 accepted \\
towards fraudulent financial reporting & \\
\hline H3a: The quality of external auditors can strengthen the influence of the & 0,020 & H5a accepted \\
composition of the independent board of commissioners towards fraudulent & \\
financial reporting & \\
\hline $\begin{array}{l}\text { H3b: The quality of external auditors can strengthen the influence of the } \\
\text { number of board of commissioners meetings on fraudulent financial }\end{array}$ & \\
reporting & & \\
\hline
\end{tabular}

Source: Data processed in 2018 


\subsection{The Influence of the Composition of the Independent Board of Commissioners Towards Fraudulent Financial Reporting}

The composition of the independent board of commissioners based on the results of the logistic regression test gives a significant negative effect on fraudulent financial reporting, that is $0.042(\mathrm{p}<0.05)$ It means that a bigger composition of independent commissioners can reduce the possibility of fraudulent financial reporting because of the tight control by independent commissioners on management. This is supported by the results of descriptive analysis, which shows that during the research period, the composition of the independent board of commissioners in the company, on average, has fulfilled the criteria set by the Financial Services Authority (OJK). It is in agreement with the financial service authority regulations (POJK) No 33 of 2014 which states that the number of independent commissioners must be at least $30 \%$ of all commissioners, and this has been proven through the results of a descriptive analysis test where the average value of the independent board of commissioners variable is $44,36 \%$.

Based on the results of the test of the significance of logistic regression and descriptive statistical tests Hypothesis 1 which states the composition of the board of commissioners gives a negative effect towards fraudulent financial reporting accepted and $\mathrm{H}_{0}$ rejected. The addition of independent commissioners in the companies studied was able to fulfill the regulations of the FSA. The result of this research is supported by research conducted by Chen et al. (2006), Razali and Arshad (2014) which prove that independent commissioners influence reducing the possibility of fraudulent financial statements. Because the bigger the proportion of independent commissioners, it will be able to minimize fraud in presenting the financial report.

\subsection{The Influence of the Number of Board of Commissioner Meetings Towards Fraudulent Financial Reporting}

The significance test results through logistic regression variable number of board of commissioner meetings obtained a value of 0.025 ( $\mathrm{p}<0.05$ ). This means that the more frequent frequency of board of commissioner meetings can prevent or reduce the possibility of fraudulent financial statements. This result is supported by the results of descriptive statistical tests where this variable is worth an average of 5.86, which means that the average observation company does five times to 8 times a year. Also, most companies observe board of commissioners meetings six times a year. It shows that if the observation company has followed the rules of the financial services authority Number 33 article 31 of 2014 which states that the board of commissioners must hold a meeting at least once in two months. Based on the results of the logistic regression test and also the results of descriptive statistics Hypothesis 2 which states the number of board of commissioner meetings has a negative effect on fraudulent financial reporting accepted and $\mathrm{H}_{0}$ is rejected. The attitude of having a company triggers the board of commissioners to optimize its performance, the existence of good coordination between members mediated by the board of commissioners meeting is able to facilitate their duties, so that the meetings are not only routines and formalities to fulfill regulations (Keuangan, 2014). The result of this test is in accordance with the research conducted by Mahesarani (2015) which states that the number of board of commissioner meetings affects the possibility of fraudulent financial report. Research conducted by Salleh et al. (2016) also states that there is a significant influence between the frequency of board meetings towards corporate fraud.

4.7 The Influence of the Quality of External Auditors and the Composition of the Independent Board of Commissioners Towards Fraudulent Financial Reporting

The results of the logistic regression test showed that the variable quality of external auditors and the composition of the board of commissioners was 0.020 ( $p<0.05$ ). It means that the quality of external auditors can strengthen the influence of the composition of independent commissioners on the possibility of fraudulent financial reporting, with auditors used by Big 4 affiliated companies. Based on these results Hypothesis 3a which states that the quality of external auditors can moderate the composition of independent commissioners gives a negative effect on fraudulent financial reporting is accepted and $\mathrm{H}_{0}$ is rejected. The results of this test are based on the research conducted by Herawati (2008) that management earning can be minimized by monitoring mechanisms conducted by independent commissioners and also external auditors. 
4.8 The Influence of External Auditor Quality and Number of Board of Commissioners Meetings Towards Fraudulent Financial Reporting

The result of the logistic regression test is on the variable quality of the external auditor, and the number of board of commissioner meetings is equal to $0.016<0.05$. This means that the quality of external auditors can strengthen the influence of the number of board of commissioner meetings on the possibility of the fraudulent financial reporting. Based on the results of the test Hypothesis $3 \mathrm{~b}$ which states that the quality of external auditors can moderate the number of board of commissioners gives a negative effect on fraudulent financial reporting is accepted and $\mathbf{H}_{0}$ is rejected. The existence of good communication between external auditors and the board of commissioners, close the opportunity for management to deal more with external auditors that have the potential to influence the audit result before it is submitted to the board of commissioners which will later be discussed at the board of commissioners meeting. The results of this test are by the research conducted by Buchanan et al. (2018) if the existence of communication that is often done between auditors and the board of commissioners will prevent the management from step in opportunistically in conducting management earnings.

\section{Conclusion}

The finding of this study suggests that the composition of Independent Commissioner and the number of Board of Commissioner Meeting have a negative and significant effect towards the fraudulent financial reporting. The quality of external auditor can strengthen the effect of the independent board of commissioner composition and the number of board of commissioner meeting towards the fraudulent financial report.

There are obstacles or weakness of this research which then categorized as the limitation. In this research, the writer only counted the composition of an independent board of commissioner and did not investigate further about the activity of the board of commissioner. Therefore, it needs development and further improvement for a better study in the future. Some recommendations for further research are: (1) Enlarge the observation period for a bigger number of samples. Enlarging the samples can be done by adding some other sectors and included all companies listed in BEI, thus not only the companies sanctioned by OJK. (2) More in-depth research needs to be done encompassing the activities of the board of commissioners and external auditor. (3) Add variable or other predictors which can influence fraudulent financial report.

\section{References}

Apriliana, S., \& Agustina, L. (2017). The Analysis of Fraudulent Financial Reporting Determinant through Fraud Pentagon Approach. Jurnal Dinamika Akuntansi, 9(2), 154-165. https://doi.org/10.15294/jda.v7i1.4036

Buchanan, J., Commerford, P. B., \& Wang, D. E. (2018). Can Increasing Auditor Security Deter Managers' operational Opportunists? The Importance of Communication with The Board and Consistency with Peer Behavior. Paper presented at the International Symposium on Audit Research, Georgia.

Chen, G., Firth, M., Gao, D. N., \& Rui, O. M. (2006). Ownership structure, corporate governance, and fraud: Evidence from China. Journal of Corporate Finance, 12(3), 424-448. https://doi.org/10.1016/j.jcorpfin.2005.09.002

Herawaty, V. (2009). Peran praktek corporate governance sebagai moderating variable dari pengaruh earnings management terhadap nilai perusahaan. Jurnal Akuntansi Dan Keuangan, 10(2), 97-108. https://doi.org/10.25105/mraai.v10i2.1016

Ismiyanti, F., \& Prastichia, C. (2015). Mekanisme Corporate Governance dan Kecurangan Laporan Keuangan [Mechanisms of Corporate Governance and Financial Statement Fraud]. DeReMa (Development Research of Management): Jurnal Manajemen, 10(2), 200-226. https://doi.org/10.19166/derema.v10i2.171

Jensen, M. C., \& Meckling, W. H. (1976). Theory of the firm: Managerial behavior, agency costs and ownership structure. Journal of Financial Economics, 3(4), 305-360. https://doi.org/10.1016/0304-405X(76)90026-X

Keuangan, O. J. (2014). Peraturan Otoritas Jasa Keuangan Nomor 33/POJK. 04/2014 tentang Direksi Dan Dewan Komisaris Emiten Atau Perusahaan Publik.

Khlif, H., \& Samaha, K. (2016). Audit committee activity and internal control quality in Egypt: does external auditor's size matter?. Managerial Auditing Journal, 31(3), 269-289. https://doi.org/10.1108/MAJ-08-2014-1084

Lukviarman, N. (2016). Corporate Governance Menuju Penguatan Konseptual Dan Implementasi Di Indonesia. Solo: PT Era Adicitra Intermedia. 
Mahesarani, D. S., \& Chariri, A. (2015). Pengaruh Tata Kelola Perusahaan Terhadap Potensi Kecurangan Laporan Keuangan. Fakultas Ekonomika dan Bisnis.

Mutmainnah, N., \& Wardhani, R. (2013). Analisis dampak kualitas komite audit terhadap kualitas laporan keuangan perusahaan dengan kualitas audit sebagai variabel moderasi. Jurnal Akuntansi dan Keuangan Indonesia, 10(2), 147-170. https://doi.org/10.21002/jaki.2013.08

Nazarudin, N., Suliyanto, S., \& Pinasti, M. (2014). Pengaruh Dualitas Peran Dan Kompetensi Anggota Dewan Komisaris dan Direksi Terhadap Manajemen Laba Dengan Kualitas Audit Sebagai Variabel Pemoderasi. Jurnal Akuntansi dan Keuangan: Research, Invent, Solve and Share, 1(1), 33-55.

Priantara, D. (2013). Fraud auditing \& investigation. Jakarta: Mitra Wacana Media.

Rahmadani, S., \& Haryanto, H. (2017). Pengaruh Ukuran Dewan Komisaris Dan Keaktifan Komite Audit Terhadap Praktik Manajemen Laba Dengan Audit Eksternal Big Four Sebagai Variabel Pemoderasi (Studi Empiris pada Perusahaan Manufaktur yang terdaftar di Bursa Efek Indonesia Tahun 2013-2015). Fakultas Ekonomika dan Bisnis. https://doi.org/10.17977/um004v5i12018p046

Rahmadhalina, C., \& Chariri, A. (2016). Karakteristik komite audit, kualitas auditor, dan fraudulent financial reporting (Studi Empiris pada Perusahaan Non Keuangan yang Terdaftar di Bursa Efek Indonesia Tahun 2008-2012). Fakultas Ekonomika dan Bisnis.

Razali, W. A. A. W. M., \& Arshad, R. (2014). Disclosure of corporate governance structure and the likelihood of fraudulent financial reporting. Procedia-Social and Behavioral Sciences, 145, 243-253. https://doi.org/10.1016/j.sbspro.2014.06.032

Rezaee, Z. (2007). Corporate governance post-Sarbanes-Oxley: Regulations, requirements, and integrated processes. John Wiley \& Sons.

Salleh, S. M., \& Othman, R. (2016). Board of director's attributes as deterrence to corporate fraud. Procedia Economics and Finance, 35, 82-91. https://doi.org/10.1016/S2212-5671(16)00012-5

Skousen, C. J., Smith, K. R., \& Wright, C. J. (2009). Detecting and predicting financial statement fraud: The effectiveness of the fraud triangle and SAS No. 99. Corporate governance and firm performance (pp. 53-81). Emerald Group Publishing Limited. https://doi.org/10.1108/S1569-3732(2009)0000013005

Soni Warsono, P. A. D. D. K. R. (2009). Corporate Governance Concept and Model. Yogyakarta: Center for Good Corporate Governance Fakultas Ekonomika Dan Bisnis UGM.

Ujiyantho, M. A., \& Pramuka, B. A. (2007). Mekanisme corporate governance, manajemen laba dan kinerja keuangan. Simposium Nasional Akuntansi X, 10(6).

Wicaksono, G. S., \& Chariri, A. (2015). Mekanisme corporate governance dan kemungkinan kecurangan dalam pelaporan keuangan. Diponegoro Journal of Accounting, 4(4), 552-563. 